\title{
Alternative Currencies and Democratic Conflict: Some Reflections
}

\section{Albert Medina Català ${ }^{1}$ and Bernat Aritz Monge Nunes ${ }^{2}$}

Abstract: Since the crisis of the Gold Standard in the 1930s and up to the Argentinean 'Corralito', at the beginning of the 21st century, periods of crisis have historically spurred numerous academic and political debates on the international monetary system. At the same time, in recent years, the Great Recession has once more stimulated the debates concerning national autonomy and democracy vs. globalization and the ideological issues surrounding them.

The particular phenomenon we analyze in this article is the current momentum gained by the so-called alternative currencies; more in particular, we deal with the previously undetected connections of these alternative currencies with both of these debates.

\footnotetext{
${ }^{1}$ Albert Medina-Català. Economista por la Universidad Pompeu Fabra . albert.medinacatala@gmail.com

2 Bernat Aritz Monge Nunes. Graduado en ADE por la Universidad Pompeu Fabra. bernat776@gmail.com
}

B Clivatge, número 6

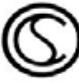


First of all, the article presents a theoretical framework of monetary economics in order to comprehend the basics of the monetary and payment systems. Secondly, it analyses the macroeconomics of both local complementary currencies (CCs) and cryptocurrencies according to this framework. Finally, it unveils the politicaleconomical implications of such currencies and, more specifically, the implications of alternative currencies with regard to the weakening or the enhancement of national democratic systems.

Keywords: cryptocurrencies, local currencies, democracy, globalization, international monetary system

Resumen: Desde la crisis del patrón oro, en la década de 1930, y hasta el "corralito" argentino, a comienzos del siglo XXI, los periodos de crisis han dado lugar a numerosos debates académicos y políticos sobre el sistema monetario internacional. Simultáneamente, en años recientes, la Gran Recesión ha estimulado una vez más los debates sobre la relación entre autonomía nacional y democracia, por un lado, y globalización, por otro, así como las discusiones relativas a las cuestiones ideológicas implicadas.

El fenómeno concreto que aquí analizamos es el impulso que han cobrado en la actualidad las llamadas monedas alternativas; más específicamente, nos proponemos abordar la relación no detectada entre dichas monedas alternativas y los debates que acabamos de mencionar.

En primer lugar, el artículo presenta un marco teórico de la economía monetaria a fin de comprender los elementos básicos de los sistemas

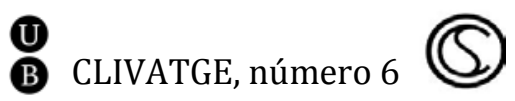


monetario y de pagos. En segundo lugar, analiza los aspectos macroeconómicos de las monedas complementarias locales (CC) y las criptomonedas según el marco teórico presentado. Por último, pone de manifiesto las implicaciones económico-políticas de ambos tipos de monedas por lo que respecta al debilitamiento o el fortalecimiento de los sistemas democráticos nacionales.

Palabras clave: criptomonedas, monedas locales, democracia, globalización, sistema monetario internacional

Resum: Des de la crisi del patró or, a la dècada de 1930, fins al "corralito" argentí, a començament del segle XXI, els períodes de crisi han provocat nombrosos debats acadèmics i polítics sobre el sistema monetari internacional. Simultàniament, en anys recents, la Gran Recessió ha estimulat una vegada més els debats sobre les relacions entre autonomia nacional i democràcia, per una banda, i globalització, per altre, a més de les discussions relatives a les qüestions ideològiques implicades.

El fenomen particular que aquí analitzem és l'impuls que han rebut en la actualitat les anomenades monedes alternatives; més específicament, ens proposem abordar la relació no detectada entre aquestes monedes alternatives i els mencionats debats.

En primer lloc, l'article presenta un marc teòric de l'economia monetària a fi de comprendre els elements bàsics dels sistemes monetari i de pagaments. En segon lloc, analitza els aspectes macroeconòmics de les monedes complementàries locals (CC) i les criptomonedes seguint el marc teòric presentat. Per últim, posa de

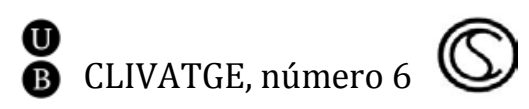


relleu les implicacions econòmic-polítiques de tots dos tipus de monedes pel que fa a l'afebliment o l'enfortiment dels sistemes democràtics nacionals.

Paraules clau: criptomonedes, monedes locals, democràcia, globalització, sistema monetari internacional

\section{Introduction}

Alternative currencies are all media of exchange that are not under the control of a Central Bank and its value is not used significantly by public administrations to enforce their rights and obligations. In other words, we can define alternative currencies as all kinds of informal circuits of money that are not under the control of the classic institutions in charge of financial and monetary affairs.

Historically, the so-called alternative currencies have gained momentum in strong correlation with economic crises (Tóth, 2011). Both the recent spread of local currencies during the Argentinean depression (1998-2002) and the global proliferation of cryptocurrencies since 2009 on can be understood as examples of alternative currencies challenging to some degree the hegemony of

B CLIVATGE, número 6

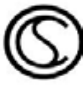


official monetary systems in times of economic crisis and beyond (Gómez, 2009).

The questioning of the role of state authorities (i.e., central banks) in monetary affairs in favour of supranational mechanisms (cryptocurrencies) or local authorities o entities (local currencies) amounts to a debate about what the competences of the state in monetary issues should be. In fact, it has only reinforced the debate about what the optimal equilibrium between global markets and national autonomy should be. On the one hand, the supporters of cryptocurrencies underrate the role of the state when they try to abolish its mandate in favour of an international market-based management (as we argue in sections 1 and 2). On the other hand, the defenders of local currencies de facto propose to undermine the centrality of national authorities. They question the state monopoly in issuing money and are willing to reduce trade and financial transactions outside a delimited local area in order to promote a "social economy" (as argued in section 2.b; see, for instance, Blanchar, 2016).

Admittedly, the debates about national autonomy are far to be new. They can be understood as recurrent dialogues about the dysfunctions of the international economy, regularly unfolding since the days of the Great Depression of the 1930s (Keynes, 1931; Polanyi, 1944; Steil, 2013). Hence, we can consider alternative currencies as a revival of past debates.

In order to discuss the role of the alternative currencies and their connections to these debates, this article will consist of: (1) an

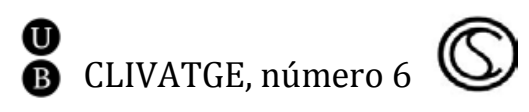


explanation of the theoretical framework that will be used; (2) a presentation of the macroeconomics of alternative currencies; (3) a discussion of the Impossible Trinity of International Economics and the role of alternative currencies; and (4) some final remarks on the relationship between globalism and democracy in current debates and the role of the present momentum enjoyed by alternative currencies.

\section{The Theoretical Framework}

In economics, alternative currencies constitute a complex subject. This is why it is probably a good idea to start out with an explanation of the theoretical framework of monetary economics on which this paper is based. The framework employed is that of the monetary and financial economist Perry Mehrling, otherwise called the "Money View" (Mehrling, 2012).

\section{a. The Hierarchy of Money}

To begin with, our theoretical framework addresses the empirical fact that, always and everywhere, monetary systems are hierarchical; that in any particular economy there exist an intrinsic hierarchy between different types of currencies and credit. One way that the economists have tried to understand this hierarchy of money is by distinguishing between money (means of final settlement) and credit (promises to pay money or, otherwise, instruments for delaying the final settlement of a contract) (Mehrling, 2000).

(U) CLIVATGE, número 6

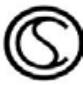


This initial distinction is useful, but it quickly falls into trouble. On the one hand, it is simplistic because it leads to the idea that there are only two layers in the hierarchy of money. On the other hand, it is too ambitious, because what counts as a means for final settlement for different types of contracts varies widely. In fact, what looks like money at one level of the hierarchy turns out to look like credit at the level above it.

To illustrate this with a simple case, in a country where the national currency is pegged at a fix rate with a certain amount of gold (a gold standard), an economic agent (for this case, an ordinary citizen with some disposable cash) can undertake, on one day, multiple economic activities which involve means of final settlement of different ranks. It can, for instance, make a loan to a friend or, in other words, create and possess an informal debt security. Securities are, for the part of the debtor (in this case our economic agent's friend), promises to pay currency over some time horizon in the future, so they are attenuated promises to pay.

It can also open a bank deposit to keep its spare cash. Deposits are promises on the part of the bank to pay currency on demand, so they are promises to pay the ultimate money with an added degree of commitment.

Additionally, it can simply use its cash to buy different products in the supermarket next to his home. In other words, it can meet sales contracts by paying directly with banknotes. Currency in the form of paper currency and coins of legal tender are ultimate money for national transactions, which means that every person is obliged to

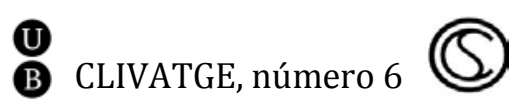


accept them as a valid method of payment within the national jurisdiction (Mehrling, 2000). However, it could also pay with a debit card, by which the final settlement for this transaction would simply be a transfer from one bank deposit to another bank deposit, with no need of using coins and banknotes.

Also, and finally, let's suppose our economic agent wants to buy products from another country which with its own national currency fixed to a certain quantity of gold. The citizen in question could demand to his or her national authorities the corresponding amount of gold in exchange for its cash and use the gold obtained to buy the currency of the other country where he or she wants to buy products from. Then, from an international perspective, that cash in a particular national currency would not be ultimate money, as it would not be recognized by another country's national authorities as an official means of final settlement. It is therefore clear that cash in a national currency is, in its turn, a promise to pay gold, which would be internationally the ultimate money in this instance. In any other case, for a national currency to be a de facto means of final settlement, the citizen and the seller should strike a bilateral deal by which the seller accedes to accept cash in a foreign currency at his own expense.

These simple examples allow us to illustrate a simplified but quite accurate general hierarchy of money that operated up until the 1930s with some country-specific exceptions and also some relevant historical exceptions (notably World War I). This general hierarchy of money was made up of the following general layers: (1) gold; (2) national currencies; (3) bank deposits; (4) securities.

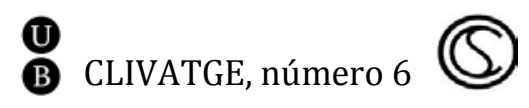


In such a world, gold is the ultimate money because it is the ultimate international means of payment. National currencies are a form of credit in the sense that they are promises to pay gold. Bank deposits, in their turn, are promises to pay currency on demand, so they are twice removed promises to pay the ultimate money. And securities are promises to pay currency over some time horizon in the future, so they are even weaker promises to pay.

As it becomes immediately apparent, the credibility of these different promises of payment is crucial in order to guarantee the certainty and overall functioning of the international monetary and payment systems. To guarantee all such promises at different levels, states can put into place institutions that enhance the credibility of the promises through their pre-emptive effects and their interventions when needed. Moreover, states can pass and enforce laws that regulate the behaviour of private economic agents in order to increase the soundness and credibility of the monetary and payment systems. Besides all these actions by public authorities, private parties can also increase the credibility of their promises through different instruments and contractual guarantees.

As a very classic example, national currencies in a gold standard are backed by gold reserves, which means that the national authority holds some proportion of gold reserves available relative to the currency in circulation. When a currency in gold standard is backed by gold reserves, it is still a promise to pay, but it is simply a more credible one because the presence of reserves makes it more likely

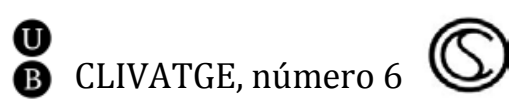


that the issuer of currency can fulfil its promise if called upon to do so. In Mehrling's words:

In this hierarchy, where is the dividing line between money and credit? It is tempting to draw the line between currency (and everything above it) as money, and deposits (and everything below it) as credit.

The source of this temptation is the institutional fact that currency is the final means of settlement for domestic payments. Just so, for a bank settling its accounts at the end of the day, currency or "high-powered money" is certainly the means of settlement. But things look different farther down the hierarchy.

For ordinary people like ourselves, bank deposits are the means of settlement. Hence we might be inclined to view deposits (and everything above them) as money, and securities as credit. This is more or less what most modern textbooks mean when they speak of the money supply, although even here there is some ambiguity which is reflected in the various definitions of money: M1, M2, M3 and so forth.

And things look different farther up the hierarchy as well. For a country settling its accounts at the end of the day, national currency is of limited value. What other countries want is their own currency, or the international means of settlement, which means gold in the case of a gold standard, perhaps SDRs (Special Drawing Rights at the IMF) in the modern case. (The US is an exception because of the international role of the dollar.) (Mehrling, 2016: 7).

B Clivatge, número 6

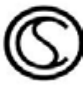




\section{b. The Three Prices of Money}

Based on the aforementioned four general forms of money and/or credit, it is possible to derive three prices of money for the conversion between the different forms of it:

1 . The exchange rate, which is the price of the national currency in terms of a quantity of gold or, in contemporary times, the price of the national currency in terms of other national currencies.

2) The deposits par, which is the price of deposits in terms of currency, being a promise to pay currency on demand qualitatively less valuable than the currency itself. Banks can face runs and bankruptcies and therefore banks face a pressure to defend the parity between deposits and their amount of cash reserves.

3) The interest rate, which is the price of securities in terms of currency or deposits, assuming par.

\section{c. The Hierarchy of Market Makers}

As previously stated, in order to guarantee the promises of payment at different levels, states can put into place institutions that enhance the credibility of such promises due to their pre-emptive effects and through their intervention when it is needed. Moreover, they can pass and enforce laws that regulate the behaviour of private economic agents in order to increase the soundness of the financial and payment systems.

The most typical and evident top financial institution within a country is the National Central Bank of that state. Central banks are typically in charge of macro managing Foreign Exchange operations;

B Clivatge, número 6

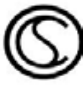


assessing the health of the national financial system (with a special emphasis on the banking system and the depository institutions); and acting as a clearinghouse for the banking system by providing it with liquidity through some key interest rates and acting as a lender of last resort when needed.

It is clear that typical operations of a central bank do not only include their role as a regulatory and an institutional guarantee, but also a crucial role as a market maker within the financial system (Mehrling, 2016; p. 12), being able to intervene and influence all three prices of money. In other words, it also acts as a sort of security dealer-an economic agent that stands ready to buy or sell securities at given prices and doing so by holding an inventory of both securities and currencies (foreign and national).

From the 4 layers of the hierarchy of money, we can similarly draw a general hierarchy of three main financial market makers for any given country (Mehrling, 2016; p. 13): (1) The National Central Bank; (2) the country's banking institutions; and (3) private (or public) security dealers. As Mehrling puts it:

The point is that there is a simple hierarchy of market makers to go along with the hierarchy of instruments. And for each market maker, there is an associated price of money. The prices in the simple hierarchy are three: the exchange rate (the price of currency in terms of gold), par (the price of deposits in terms of currency), and the rate of interest (the price of securities in terms of deposits or currency, assuming par). These prices are the quantitative link between layers of qualitatively differentiated assets (...)

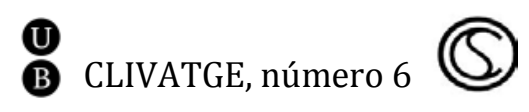


If the market makers do their job well, we will observe continuous markets at the various prices of money. In other words, the qualitatively differentiated hierarchy will appear as merely a quantitative difference between various financial asset prices. It is this transformation from quality to quantity that makes it possible to construct theories of economics and finance that abstract from the hierarchical character of the system (as most do). But the hierarchical character remains, and shows itself from time to time, especially when the market makers are not doing their job well, such as during periods of financial crisis or under the extreme stress of war finance.

Even in less extreme times, fluctuation in the natural hierarchy shows up as strain on the market-making institutions (Mehrling, 2016: 12-13).

\section{d. The Dynamics of the Hierarchy of Money in Time}

As it has been hinted at already, the developments taking place within the hierarchy of money are dynamic, with numerous fluctuations and cycles:

At almost any time scale you care to examine, it is a system in motion. Focus your attention on daily clearing and settlement, on the business cycle frequency, or on the longer term secular scale, and you'll see constant flux: daylight overdrafts, credit cycles, wars and depressions. At every time scale, we see expansion and contraction of the hierarchy.

B Clivatge, número 6 
As it expands, the hierarchy flattens and the qualitative difference between credit and money becomes attenuated, but then the system contracts and the hierarchy reasserts itself. At the business cycle frequency, the phenomena surrounding this contraction and reassertion are grouped under the headings "irrational exuberance" in the expansion phase and "financial crisis" in the contraction phase (Mehrling, 2016: 10).

There are two dimensions to these fluctuations: a quantitative one and a qualitative one. The former refers to the expansion and contraction of the quantity of credit which takes place at all levels of the system. The latter, more subtle, has to do with the quality of credit, which tends to increase during an expansion and decrease during contractions. To some extent, we can see this qualitative fluctuation directly as a fluctuation in the availability of credit to marginal borrowers and the rates charged to different borrowers according to their differences in quality. Again, in Mehrling's words:

At all times, the monetary system can be characterized by the balance between these two dimensions. The history of monetary theory is to a large extent comprised of a dialogue between two points of view, often distinguished as the Currency School versus the Banking School, which emphasize respectively the importance of scarcity and the importance of elasticity. [...] Both have part of the truth but neither has it all. Thus, liquidity is at the same time both naturally scarce and naturally elastic (...)

B CLIVATGE, número 6

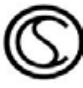


The natural scarcity comes from the fact that agents at any particular level in the hierarchy cannot by their own actions increase the quantity of the forms of money at a higher level than themselves.

Just so governments cannot increase the quantity of gold, and banks cannot increase the quantity of government currency. The availability of money thus serves as a constraint that holds the system back in its attempts to expand.

The natural elasticity comes from the fact that agents at any particular level in the hierarchy can, by their own actions, increase the quantity of forms of credit at their own level, and possibly also below them. If you and I want to make a trade and you are willing to accept an IOU (a promise to pay) from me, then we can trade and what makes the trade possible is an expansion of credit.

The elasticity of credit thus serves as an element of freedom that facilitates breaking loose from any constraint that may be standing in the way of expansion.

This natural elasticity applies to banks as well. By trading among themselves, banks can and do break loose of the constraint of central bank reserves. The important point is that the system involves at all times a balance between discipline and elasticity, with sometimes one and sometimes the other serving as the more dominant feature (Mehrling, 2016: 11-12).

\section{The Macroeconomics of Alternative Currencies}

In this paper, we adhere to the following definition of what an alternative currency is: All pretended medium of exchange that is not legal tender by the current national jurisdiction of the Central Bank and it is not used as a unit of account by Public Administrations in

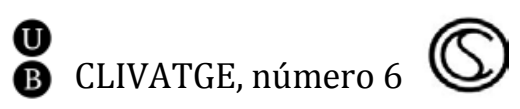


expenditures and/or taxes. The academic literature identifies two main types of alternative currencies: complementary local currencies (or CCs) and cryptocurrencies (or virtual currencies).

There are some factors shared by both kinds of alternative currencies, as opposed to official currencies, and some differences within alternative currencies framework that can be preliminary summarized as follows:

1. Neither of them has a national dimension. Instead of this, alternative currencies may have a global or a local approach-if we except the recent impulse given to cryptocurrencies by some governments (e.g., Venezuela's Petro).

2. Its existence is partially justified for ideological reasons. Local currencies pretend to promote a local way of life. Cryptocurrencies aim to abolish central bank discretion.

3. There is no possibility for these currencies to have a reserve currency status. Local currencies do not aim to compete with official currencies in the hierarchy of money and are not robust enough to become a safe asset in company's portfolios indefinitely. Cryptocurrencies aim to dispute the hierarchy of money with the official currency, but their characteristics (see below) and their lack of a stable store of value reduce their attractiveness as an asset in the long-run.

4. Both projects share some criticism of the role of central authorities in the policy-making process, but from different ideological perspectives.

\section{B Clivatge, número 6}

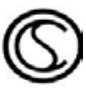


Regardless of these shared characteristics, the main macroeconomic implications of the rule of money are rightly exemplified by Daron Acemoglu, David Laibson and John A. List in their approach to the role of the state in designing countercyclical policies in case of crisis (Acemoglu, Laibson and List, 2016: 330-350). In short, the authors hold that, for any fiscal and/or monetary policy oriented to increase employment and GDP, the complicity of official monetary and financial authorities is needed. Consequently, alternative currencies can play a role in modifying the levels of state discretion in policy-making, but only up to a certain extent.

\section{a. The case of Complementary Community or Local Currencies}

A complementary community, or local, currency (CC onwards) is money used within a limited local territorial area directed to enhance the local economy. It is used by a community of inhabitants with the goal of promoting reciprocity among nearby agents and making the local market prevail to the detriment of other national or international transactions (Blanc, 2011).

Their local or communitarian approach has historically been founded upon the criticism of the lack of capacity of the monetary policies of the central bank in order to overcome local socioeconomic problems. More specifically, the resource to CCs derives from the inability of official monetary policies to be expansive enough to address local problems-e.g. territorial disequilibria, high unemployment, lack of protection of a specific way of life... The goal

B CLIVATGE, número 6

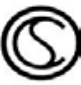


of CCs is to increase the levels of domestic demand and production through two mechanisms: on the one hand, by incentivizing local transactions, and on the other, by generating a phenomenon akin to a monetary expansion.

One of the characteristics of CCs is their lack of ambition concerning the scale effects of the currency. Generally, the territorial delimitation of the currency is fixed and relatively small in comparison with the territory in which the official currency is used and with respect to the total volume of transactions undertaken (e.g., the Bristol Pound is limited to the city of Bristol; the Eco coin is limited to an Ecoxarxa, etc.).

How Do Complementary Community or Local Currencies Work According to Our Theoretical Framework

When we analyzing CCs from the point of view of our theoretical framework, they turn out to be a type of currency that, regardless whether they are virtual or physical, would always and in any case sit below the official national currency in the hierarchy of money. Thus, they are a qualitatively inferior kind of currency.

The main reason for this is that a CC would not be legal tender strictu sensu. Economic agents and the local authority in question may be able to make settlements in CC and even local taxes may be collected in CC, but other transactions and payments of taxes with other state administrations still have to be paid using the official currency; the state's legal tender.

B CLIVATGE, número 6

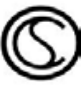


The convertibility of a CC with the national official currency is key to further understand why a CC is a qualitatively inferior kind of money within the framework of the money hierarchy (convertibility means the ease with which a CC can be exchanged for the official currency).

In order to ensure the sufficient credibility of a CC and make its use practical, a local authority has to make the CC convertible with the official currency. By this, a local currency would be nothing but a promise to pay official currency. Thus, there would be a qualitatively hierarchical relation between the two currencies (CC being at the lower end) and, as a consequence, a quantitative price of money between the two (an exchange rate).

The local authority would act de facto as a local central bank. The hierarchical relationship between the two currencies would be matched by a corresponding hierarchical relation of market makers (i.e., the local authority would be below the National Central Bank).

The local authority would have the monopoly of issuing CC and would perform, de facto, other traditional actions of a central bank within the local context, such as providing liquidity in the form of CC, managing the exchange rate operations between the $\mathrm{CC}$ and the official currency, supervising the systems of payment in CC, and so on. Additionally, the local authority would probably perform actions akin to a banking or depository institution by creating a service of deposit accounts for people and companies so they could make payments in CC with more ease.

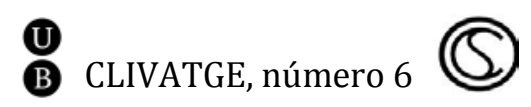


How a Local Authority Can Tackle Local Problems According to Our Theoretical Framework

The essential reason why a CC works in softening socioeconomic problems is essentially that it is a currency which is under the control of the local authority and, therefore, offers elasticity for credit. This local authority can in turn reinforce the transactions between local agents and, besides that, generate a phenomenon similar to a monetary expansion.

If a local institution puts a CC into circulation in the local economy through the payment of subsidies or salaries-accompanied by some previous logistical preparations-, when given the choice to spend either a CC or the official currency, the economic agents who receive this $\mathrm{CC}$ will have incentives to fulfil their commitments with the CC and reserve the official currency for other purposes in transactions with agents outside the local scope who do not recognise the $\mathrm{CC}$ as a valid means of payment. Thus, there will be an incentive to spend the currency of lower qualitative value and reserve the official currency of higher quality as much as possible.

Hence, the involved economic agents will tend to reorient their spending as much as possible towards individuals and businesses who accept this alternative "lower" currency. And those who do not initially accept it will find incentives to join in. The reason is that, if they do not, they will lose sales and these sales will be captured by other individuals and businesses who do accept the CC.

(U) CLIVATGE, número 6

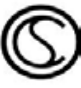


Besides this reorientation effect, the local authority will be able to generate a phenomenon akin to a monetary expansion. As we have explained in the discussion of our theoretical framework for the case of a currency pegged to a quantity of gold, a central bank can increase the credibility of its promise to keep the exchange rate between the national currency and gold by holding some proportion of reserves of gold relative to the currency in circulation. A local authority can do the same thing in the case of a CC. It can keep reserves of the official currency in order to back its promise of exchanging the $\mathrm{CC}$ for the official currency at a certain rate. Nonetheless, it will still be able to issue an amount of CC higher than the amount of reserves; therefore, it will be able to inject more resources for different public policies and economic activities at a lesser cost in euros than originally. This phenomenon will be akin to a monetary expansion, and hence, the local authorities will be able to generate more economic activity and inject more resources to tackle socioeconomic problems.

\section{b. The Case of Cryptocurrencies}

The case of cryptocurrencies is a different kettle of fish. Cryptocurrencies are virtual money that can be ruled without bank and institutional intermediation. In essence, it is a parallel system of transactions and payments.

As it was mentioned above, the main characteristic of cryptocurrencies is their globalist ambition (in contrast to CCs). Such ambition comes at the cost of some impediments, like its lack of what is defined by the literature as "public goods" (Kindleberger, 1986). In

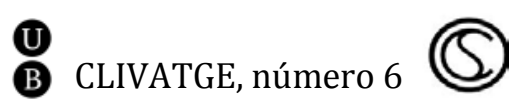


other words, cryptocurrencies have proved to be unable to promote a secure framework to maintain ordinary transactions in the economy.

In particular, stability and an agile performance in the trade system and security of property rights are absolutely necessary conditions to promote effectively its global ambition. In the case of cryptocurrencies, these conditions, which are accomplished by the official institutional monetary systems, have been substituted by blockchain functioning, which is unable to promote stability due to its lack of political discretion.

This lack of political discretion is the source of the ideological bias in cryptocurrencies' support. In essence, cryptocurrencies supporters stand for the privatisation of the public monopoly of issuing money. The point can be summarized in the words of $\mathrm{F}$. V. Hayek in 1977: "There is no justification in history for the existing position of a government monopoly of issuing money" (Ametrano, 2014). Thanks to blockchain, a central monetary authority is hypothetically no longer needed and the supposed privacy and efficiency gains due to these reasons are significant for cryptocurrency supporters. These approximations to the nature of cryptocurrencies give us a hint of the strong anti-state inspiration behind this new monetary world.

All the limitations to the global ambition of cryptocurrencies that were mentioned above are only increased in case of state belligerency against them. If the national opposition is active and national fiscal authorities demand their tax revenues exclusively in the national

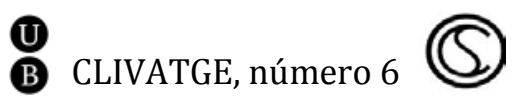


currency-as they almost always do-, the practicality of cryptocurrencies faces a severe blow.

Moreover, if the State simply puts the regulation standards for this emerging sector on a level with those for other sectors, as some economists have pointed out recently, a collapse of cryptocurrencies' value is plausible (Myers, 2017). What the empirical evidence has shown us so far is that a simple institutional belligerency has reduced cryptocurrency expansion in a matter of months and we do not have enough evidence to think that this will not occur in the future (see, for example, the case of the People's Bank of China intervention in the early 2016: Hileman and Rauchs, 2017: 32; Ly, 2012).

How Cryptocurrencies Work According to Our Theoretical Framework

In terms of the theoretical framework presented at the beginning of this writing, cryptocurrencies display an ambition to position themselves at the top of the hierarchy of money; in other words, they aspire to become the international ultimate money. Moreover, if their supply is limited beforehand, this implies that cryptocurrencies would have the role of reinforcing the phenomenon of the scarcity of ultimate money.

National currencies would hypothetically be below the cryptocurrency in question; they would be promises to pay cryptocurrency. This qualitative hierarchy would translate into a quantitative price (an exchange rate) between the national currencies and the cryptocurrency.

(U) CLIVATGE, número 6

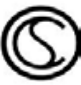


The fatal flaw of this approach is that cryptocurrencies do not possess the effective potential to be at the top of the international hierarchy of money because their alleged superior hierarchical position is not matched by the necessary institutional hierarchy of market makers.

By definition, cryptocurrencies are not backed by an institutional authority operating (among other things) as a market maker. The idea that a cryptocurrency has the intrinsic characteristics to become an international ultimate money obviates two of the most ancient reasons for the need of a central bank: first of all, its necessary role as a clearing house for banks, and secondly, its necessary role as lender of last resort.

In layman's terms, the clearing house role refers to an officially approved marketplace for banks to improve their coordination. It allows the banking system to engage in multilateral relations among them (especially important for refinancing). This presents very important gains of efficiency when compared to the numerous bilateral interactions between banks if such clearing house did not exist.

The role of lender of last resort basically refers to the role of central banks as a bank for other smaller banks, to the capacity of central banks to inject liquidity to banks through loans at low interest rates when the scarcity of ultimate money kicks in a financial crisis (Mehrling, 2016; p.5-6).

B CLIVATGE, número 6

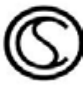


This is a fundamental role that no authority would be able to perform in a world where a cryptocurrency were at the top of the hierarchy of money.

\section{The Impossible Trinity of International Economics and the Role of Alternative Currencies}

All the previous reasoning about the internal paradoxes of alternative currencies goes well with the traditional macroeconomic framework of international economics known as the "Impossible Trinity" (fig. 1).

The model, originally conceived by Robert Mundell and Marcus Fleming, considers that under open economies, fixed exchange rates, free movement of capitals and monetary autonomy are policy goals which are impossible to achieve at the same time. As a consequence, states have to give up one of the three options.

The case of the Argentinean crisis mentioned at the beginning of the article may be the clearest example. In the 1990s, the Argentinean government pegged its national currency to the dollar and followed a policy of free movement of capitals. The consequence was, de facto, a loss of monetary autonomy. This policy choice, and the lack of awareness of the implications of such a decision in economic policy, ended up having harsh consequences at the beginning of the 21st century. 


\section{Figure 1. The Impossible Trinity of International Economics}

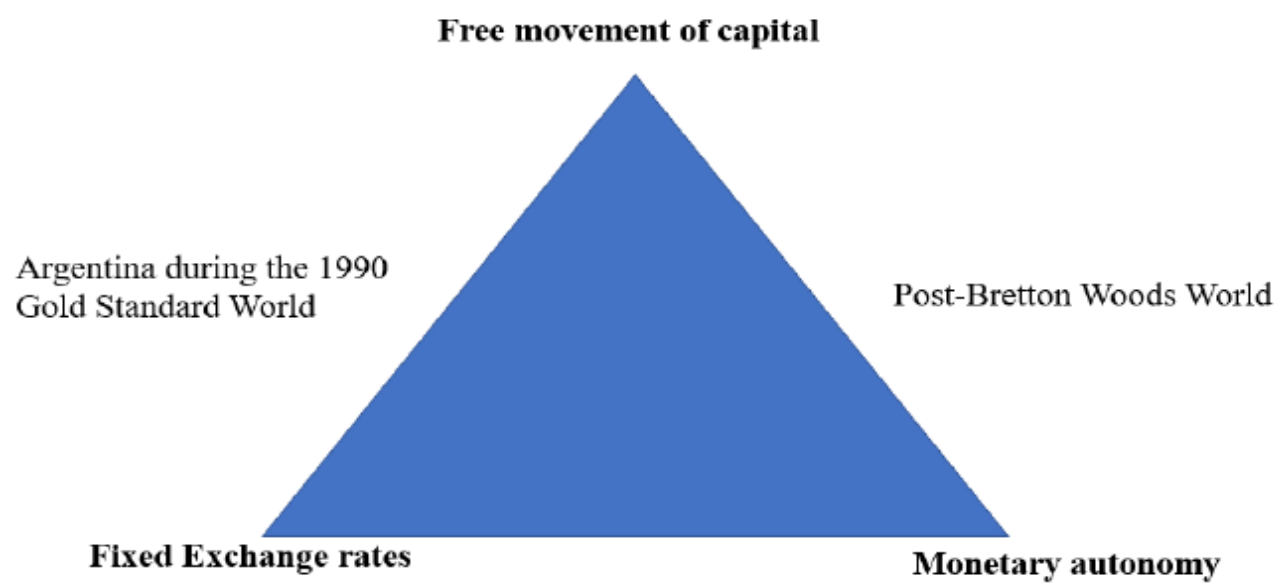

Bretton Woods World

Source: Prepared by the authors

This framework was developed in its political interpretation by Dani Rodrik (Rodrik, 2000). The Harvard economist pointed out that, in its political interpretation, the Impossible Trinity of international economics can be understood as the unviability to simultaneously achieve hyperglobalization, states rule, and democracy.

In this line of thought, the cryptocurrency approach to international economy consists of giving up the democratic

B CLIVATGE, número 6

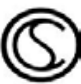


discretionality of central authorities on monetary and exchange rate policies in order to achieve greater market integration.

By contrast, the purpose of local currencies is more related to sacrificing some degrees of market integration in order to give the public authorities-in this case, sub-state administrations democratically elected-more room to manoeuvre. In other words, with a community or local currency, the result would be a decreasenot a substitution or an invalidation -in the level of centralization of the official monetary system in virtue of a new kind of subnational monetary governance. This would allow the public authorities to soften competition for the local economic agents as a consequence of a somewhat attenuated economic integration.

The main outcome of the supposed global application of cryptocurrencies is essentially summarized in a recent report by the Bank of Canada, where it is hypothesized how a "Bitcoin standard" would perform in the international economy. The report indicates that, although some central bank discretion could be maintained, the inexistence of arbitrage cost in international transactions would restrict national monetary autonomy and the consequences would be an $a$ la classical Gold Standard or something close to the outcomes of the Argentinean pegged system-i.e., deflation and fixed exchange rates (Weber, Fung, Hendry and Stuber, 2015).

It is then possible to determine that, in the case of a cryptocurrency like Bitcoin, the trilemma would manifest itself through the impossibility of maintaining at the same time a Bitcoin standard and sufficient monetary autonomy to maintain institutional

B CLIVATGE, número 6

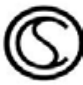


sensitiveness to popular opinion. Decentralization through a sort of Bitcoin standard would produce the effect of a more integrated international economy by reducing the transaction costs and the discretion of national central banks and public institutions in general.

In other words, in theoretical terms, the "democracy" of cryptocurrencies would imply the reduction of information and transaction costs, which would improve the coordination of individual economic agents' preferences but, at the same time, would invalidate the possibility of significant institutional intervention.

In this sense, the supporters of cryptocurrencies argue that less political discretion of public institutions will create a direct link of "free" citizens deciding the everyday value of their assets by "voting" with their wallets the value of cryptocurrencies without any intermediaries. From this point of view, the translation of the Impossible Trinity trilemma into cryptocurrency effects is that citizens give up institutions in order to link globalization and democracy. 
Figure 2. The Political Impossible Trinity of Alternative Currencies

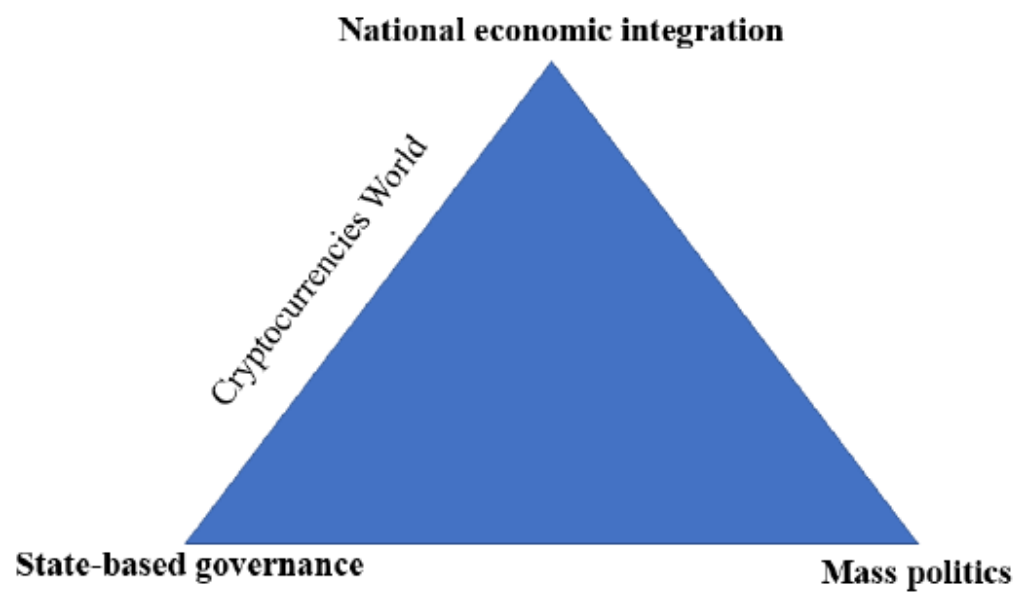

Complementary Community or Local Currencies World

Source: Prepared by the authors

According to our theoretical framework, giving up the classical policy areas of financial and monetary institutions to market integrationinstead of institutional integration-has more to do with reducing democratic standards by reducing the levels of financial regulation that protect citizens that are simply not interested in monetary and financial affairs (Figure 2).

(U)

B CLIVATGE, número 6 


\section{Final remarks}

In conclusion, in this article, we have discussed the role of alternative currencies in enhancing or reducing economic democracy.

First, we have summarized a theoretical framework which is capable to give us a better comprehension of the arguments of the discussion. Through this framework, we have explained the hierarchy of money, the three prices of money, the hierarchy of market makers and the dynamism of this hierarchy in time. Subsequently, we have used this theoretical framework to introduce the basic macroeconomics of alternative currencies. Finally, we have developed an argument that presents alternative currencies as a way of reducing the levels of centrality of national monetary policies, with two clearly different political orientations.

On the one hand, CCs may sacrifice some economic integration, while they preserve a strong link between institutions and popular sensitiveness. On the other hand, cryptocurrencies promote a kind of "individual" democracy where economic agents can vote with their feet by choosing the composition of their cryptocurrency wallets without any institutional intervention. This political preference seems incompatible with maintaining high democratic standards, in line with the role of money regulation presented in our theoretical framework. Thus, in conclusion, it seems that the global application of cryptocurrencies would only reduce democracy by reinforcing globalization.

B Clivatge, número 6

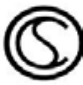




\section{References}

Acemoglu, D., Laibson, D. I. and List, J. A. (2016). Macroeconomics.

Pearson.

Ametrano, F. M. (2014). "Hayek Money: The Cryptocurrency Price

Stability Solution". SSRN Electronic Journal.

https://doi.org/10.2139/ssrn.2425270.

Blanc, J. (2011). International journal of community currency

research. Dept. of Geography, University of Leicester.

Retrieved from https://ijccr.net/2012/05/29/classifying-ccs-

community-complementary-and-local-currencies/.

"European Commission launches the EU Blockchain Observatory and

Forum". Digital Single Market. (n.d.). Retrieved February 6,

2018, from https://ec.europa.eu/digital-single-

market/en/news/european-commission-launches-eu-

blockchain-observatory-and-forum.

Gómez, G. (2009). Argentina's parallel currency: the economy of the poor. Pickering \& Chatto. Retrieved from https://www.cambridge.org/core/books/argentinas-parallelcurrency/DE626FBB573A6012F367C9AFC2362445.

Hileman, G., \& Rauchs, M. (2017). “Global Cryptocurrency

Benchmarking Study". Retrieved from

https://www.jbs.cam.ac.uk/fileadmin/user upload/research/ centres/alternative-finance/downloads/2017-globalcryptocurrency-benchmarking-study.pdf.

Keynes, J. M. (1931). "Mitigation by tariff". New Statesman and Nation, (March 1931).

B CLIVATGE, número 6

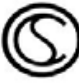


Kindleberger, C. P. (1986) "International Public Goods without International Government", The American Economic Review, 76(1), pp. 1-13. Available at: https://www.jstor.org/stable/pdf/1804123.pdf?refreqid=exc elsior\%3Aa5bed99ac881a44d0af27728ce88de8c (accessed: 22 March 2018).

Ly, M. (2012). "Special drawing rights, the dollar, and the institutionalist approach to reserve currency status". https://doi.org/10.1080/09692290.2012.644509.

Mehrling, P. (2000). “Modern money: Fiat or credit?”. Journal of Post Keynesian Economics, 22(3), 397-406. http://doi.org/10.1080/01603477.2000.11490247.

Mehrling, P. (2012). A Money View of Credit and Debt, 1" (November), 1-17. Retrieved from

https://www.cigionline.org/sites/default/files/inet2012meh rling amoneyviewofcreditanddebt.pdf.

Mehrling, P. (2016). The Economics of Money and Banking. Barnard College, Columbia University, 1-173.

Myers, J. (2017). Joseph Stiglitz: Bitcoin ought to be outlawed | World Economic Forum. Retrieved February 7, 2018, from https://www.weforum.org/agenda/2017/11/joseph-stiglitzbitcoin-ought-to-be-outlawed/.

Polanyi, K. (1985). The great transformation. Beacon Press. Retrieved from

https://books.google.es/books/about/The Great Transforma tion.html?id=D 8MAQAAIAAJ\&redir esc=y.

Đ CLIVATGE, número 6

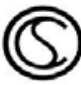


Rodrik, D. (2000). How far will international economic integration go? The Journal of Economic Perspectives, 14(1), 177-186. https://doi.org/10.1257/jep.14.1.177.

Steil, B. (n.d.). The battle of Bretton Woods : John Maynard Keynes, Harry Dexter White, and the making of a new world order.

Weber, W. E., Fung, B., Hendry, S., \& Stuber, G. (2015). A Bitcoin Standard: Lessons from the Gold Standard *. Retrieved from https://www.bankofcanada.ca/wpcontent/uploads/2015/12/bitcoin-standard-lessons.pdf. 